\title{
The Pottery Philosophical Society, 1819-1835: An Examination of the Cultural Uses of Provincial Science
}

\section{Citation}

Shapin, Steven. 1972. The pottery philosophical society, 1819-1835: An examination of the cultural uses of provincial science. Science Studies 2(4): 311-336.

\section{Published Version}

http://www.jstor.org/stable/284503

\section{Permanent link}

http://nrs.harvard.edu/urn-3:HUL.InstRepos:3353811

\section{Terms of Use}

This article was downloaded from Harvard University's DASH repository, and is made available under the terms and conditions applicable to Other Posted Material, as set forth at http:// nrs.harvard.edu/urn-3:HUL.InstRepos:dash.current.terms-of-use\#LAA

\section{Share Your Story}

The Harvard community has made this article openly available. Please share how this access benefits you. Submit a story.

Accessibility 


\title{
The Pottery Philosophical Society, I819-1835: an Examination of the Cultural Uses of Provincial Science
}

\author{
S T E VEN A. S H A P I N \\ Science Studies Unit, Edinburgh University*
}

The Industrial Revolution produced not only a new economic order, it also produced a new culture. Ideas of progress, of rationality, and, above all, of utility permeated the rapidly growing new manufacturing towns of provincial Britain and attracted many of their literate classes to an unprecedented participation in culture. Among the characteristic forums of this participation were the provincial scientific societies established throughout the late eighteenth and early nineteenth century. ${ }^{1}$ The loosely structured Lunar Society of Birmingham, founded c. I 768 , is certainly the most celebrated of these, but many others were founded during the ensuing six decades : the Manchester Literary and Philosophical Society ( $178 \mathrm{I}$ ), the Derby Philosophical Society ( 1783 ), the Leeds Philosophical and Literary Society ( 1783 ), the Newcastle-upon-Tyne Literary and Philosophical Society (I 792), the

* This work was carried out while the author was at the University of Keele, supported by a Leverhulme Visiting Fellow in the History of Science.

1 For general surveys of scientific societies see Robert E. Schofield, 'Histories of Scientific Societies: Needs and Opportunities for Research', History of Science, 2 ( $19^{6}{ }_{3}$ ), 70-83, and Douglas McKie, 'Scientific Societies to the End of the Eighteenth Century', in Allan H. Ferguson (ed.), Natural Philosophy through the Eighteenth Century (London, I 948), I 33-43. Recent studies of British provincial scientific societies include the following: Robert E. Schofield, The Lunar Society of Birmingham (Oxford, 196 $\rightarrow$ Eric Robinson, 'The Derby Philosophical Society', Annals of Science, 9 (1953), 359-67; Arnold W. Thackray, 'Medicine, Manufacturers and Manchester Men: The Origins of a Scientific Society', Proceedings of the XIIIth International Congress of the History of Science (Moscow, 1971) (in press); A. D. Orange, 'The British Association for the Advancement of Science: The Provincial Background', Science Studies, 1 (1971), 315-29 (deals with the Yorkshire Philosophical Society); Steven A. Shapin, The Royal Society of Edinburgh: A Study of the Social Context of Hanoverian Science (Ph.D. thesis, University of Pennsylvania, r97I) (chs. ii-iv deal with the Philosophical Society of Edinburgh, 1 737-82; later sections with the Royal Society into which it was subsumed in 1783). Lists of British provincial societies may be found in A. Hume, The Learned Societies and Printing Clubs of the United Kingdom (London, 1847) and J. W. Hudson, The History of Adult Education (London, 1851 ; repr. London, 1969), 237-38. References to dozens of such societies are interspersed throughout A. E. Musson and Eric Robinson, Science and Technology in the Industrial Revolution (Manchester/Toronto, 1969). 
Glasgow Philosophical Society (1802), the Sheffield Literary and Philosophical Society (1 822). There were similar institutions in Liverpool, Bristol, Halifax, Bradford, York, Whitby and elsewhere.

As yet we know relatively little about these organizations and their activities. The membership of some, notably the Lunar Society and the Manchester Literary and Philosophical Society, included distinguished men of science like James Watt, Erasmus Darwin, John Dalton and Thomas Henry and made notable contributions to the advance of scientific knowledge. But most of these societies were more concerned with inculcating and disseminating science than with contributing to its intellectual progress. A few of them survive to the present day but the majority enjoyed only a transient existence and made little impact on the national historical record. They emerged out of local cultural needs, responded to local conditions, and dissolved when, for a variety of reasons, they could no longer command the social support which had provided their initial momentum. But their failure to survive or to contribute to the advance of scientific knowledge does not diminish their historical significance. The provincial scientific societies were a cultural phenomenon of the first importance and it is well worth understanding how they came into being, responded to the cultural requirements of the classes which sustained them, prospered for a time, and ultimately declined. I shall attempt to show that science was an integral part of a class self-image and, through a detailed examination of one short-lived scientific society, I hope to illustrate some of the cultural uses of science throughout provincial Britain in the early nineteenth century.

The Pottery Philosophical Society was instituted at Hanley, North Staffordshire (in what is now Stoke-on-Trent) on the last day of $1819 .{ }^{2}$ Although a rather late foundation among provincial scientific societies, it seems to have been generally typical of similar organizations as regards structure, membership, ambitions and activities. Its Minute-Book records at least nominal activity through 1835 but it was only effective as a formal scientific institution for the first six or seven years. It produced no printed memoirs, none of its members published original science while they belonged to it, and it

2 It was sometimes referred to as the 'Literary and Philosophical Society' towards the end of its existence. An account of the Pottery Philosophical Society by H. Wells-Bladen appeared in the Staffordshire Sentinel for I June, I July, I5 July, and 19 August 19 I I under the general heading 'Philosophy in the Early XIXth Century'. A brief notice of the Society is also contained in Reginald G. Haggar, 'Some Adult Educational Institutions in North Staffordshire', Rewley House Papers, 3, no. 6 (1957-58), $12-26$ (1 2-14). I should like to acknowledge assistance in locating sources from $\mathrm{Mr}$ Haggar, $\mathrm{Mr}$ Ian Fraser of Keele University Library, Mr F. B. Stitt of the William Salt Library, Stafford, and the staff of the Horace Barks Library, Stoke-on-Trent. 
numbered only two $D B N$-stature men of science-neither of whom had yet made his reputation while a member. ${ }^{3}$

Yet one ought to be cautious about attributing to all scientific societies the aspirations and norms of the Royal Society, or even of the Manchester Literary and Philosophical Society. The technical, intellectual and cultural uses of science in the Pottery Philosophical Society must be sought in local conditions and examined in local terms. What were the conditions under which the cultivation of natural knowledge seemed desirable to certain segments of an urban, industrial society? What cultural, economic, religious, and social potential did such people see in science? How did they intend a scientific society to answer their local needs? These are the sorts of questions which will inform this examination of the brief career of the Pottery Philosophical Society.

The terms on which people appreciated and participated in natural knowledge were, like any area of culture, subject to the dominant forces and situations which shaped their collective lives. There were three major facts which influenced the conditions of existence in the North Staffordshire Potteries in the early nineteenth century. Primary was the earthenware and china industry which, apart from coal mining, was almost the sole local source of wealth for the middle classes. Upon it rested the fortunes of the district and its residents' hopes for future improvement. In general a highly traditional industry, it had been stirred to scientific, technical and artistic innovation largely by one man-Josiah Wedgwood, FRS, FSA (I 730-95). The families which owned pot-works constituted the local elite; approximately 135 such firms were listed in an 18 I 3 directory, but at most half a dozen of them had national reputations. Second was the sense of physical and social isolation. Perched on the northern tip of Staffordshire, the Six Towns which constituted the Potteries shared with Wolverhampton, in the extreme south, the distinction of being the county's only industrial centres. Because its staple product was so specialized, and because its industrial

3 William Charles Linnaeus Martin (1798-1864) was the son of a Manchester naturalist and drawing-master. He was a surgeon in Shelton when he joined the Society in December 1820, resigning five years later. From 1830 to 1838 Martin was Superintendent of the Museum of the Zoological Society of London and published approximately 45 papers in its Proceedings. Joseph Barnard Davis (180I-8I) was born in York and came to the Potteries as a surgeon some time after 1820 , having been licensed by the London Society of Apothecaries. He joined the Philosophical Society in January 1824. Long after the Society became defunct Davis obtained his M.D. from St Andrews and was elected FRS. He collected a vast craniological museum and, although he remained in the Potteries, was an editor of the Journal of Anthropology from 1869 to 1871 . (Both DNB.) 
character contrasted so strongly with its immediate environs, people of the Potteries tended to feel more isolated than their geographical situation might indicate. Their cultural contacts gravitated towards Manchester (about forty miles north) and, to a lesser extent, towards Birmingham (slightly farther to the south). The children of the middle classes in this overwhelmingly non-conforming district were sent for education, if fortunate, to the Scottish universities or to the dissenting academies of Cheshire, South Lancashire or Derbyshire, rather than to Oxford or Cambridge. The Anglican gentry of the outlying area had a markedly different cultural orientation from the manufacturing middle classes of the Potteries. Despising the smoke and squalor of the towns, they took a minimal share in industrial or municipal affairs.

Third was the influence of population and local politics in determining what could or could not be accomplished by collective endeavour in the Potteries. The Six Towns (Hanley, Burslem, Stoke, Tunstall, Longton, and Fenton) were not federated into Stoke-on-Trent until early this century; in the early nineteenth century they amounted to six fiercely independent towns. In I 80 I the Six Towns had a population of roughly 25,000; by I 831 , over 50,00o. The lack of a joint corporate structure was exacerbated by poor transportation between the towns, with the result that what was, in fact, a middling-sized industrial town acted like six small ones. Hanley (and its contiguous village of Shelton) represented the largest entity in 1831 -at 16,000 , about a third of the total. Something of a commercial and cultural centre for the district, its middle-class clientele offered employment to eight surgeons and nine attorneys-a larger number than in any of the other towns. ${ }^{4}$

While the manufacture of earthenware and china, together with subsidiary industries like the production of glaze colours, yielded up wealth to the successful capitalist, the district offered him little to do with his leisure time, and even less in the way of cultural outlets suitable to his class. He needed a forum for cultural self-expression which would at once reflect his values and identify him as a progressive and enlightened member of the local elite -an organization which would ideally, but not necessarily, do something useful for the economic activities on which the district's livelihood depended. Life in any new manufacturing town was a monotonous one, according

4 By way of local contrast the borough of Newcastle-under-Lyme, just several miles to the west, was of a more genteel character than the heavily industrial Six Towns of the Potteries. Although Newcastle had a population of 4,604 in 1801 , and 8,192 in 1831 , it supported nine attorneys and a like number of surgeons at the later date. 
to one local commentator perhaps less dreary elsewhere than in the Potteries in which

in consequence of our great destitution of innocent recreations, monotonous thoughts, instead of edifying conversation, employ the mind ... Destitute of public walks, or promenades, or public baths, or open fields, and in fact of every public place of resort, we look forward with pleasure to... lectures and concerts. $^{5}$

A scientific society was, among other things, a way of filling a dangerous cultural void. But why it was science that was chosen to fill that void, and how science served the function of marginal culture, are complex questions.

On New Year's Eve I 8 ig a meeting of eight Hanley men ${ }^{6}$ at the home of a local printer resolved 'that a Society should be formed instituted the "Pottery Philosophical Society"... for the purpose of propagating and extending useful and scientific knowledge'.? This small group then solicited the support of about a dozen more potters and professional men and held their first general meeting at a Hanley inn on 20 January 1820 . Of this founding group about half were owners of pot-works or manufacturers of glazes, three were nonconforming ministers; there were two medical men (a surgeon and a physician), one printer (who also functioned as a druggist), and one attorney. During the first year of its existence, the Philosophical Society was joined by several more surgeons and potters, but never included more than 25-30 members at a time.

The Society's first Secretary was the attorney, hence the long list of thirtytwo rules adopted at the first general meeting may reflect an outburst of professional enthusiasm as well as a deeply rooted concern among the members for an image of order and respectability. 'Order is the mainspring of a Society', their motto read, 'and without this it becomes lifeless and inanimate, defeats its primary intentions, ruins its interests, and at length becomes dissolved altogether. ${ }^{8}$ But the Philosophical Society's ultimate demise was

5 The Espalier; or, North Staffordshire Journal of Literature and Science (December 1839), 65 [In the Horace Barks Library]. The lectures referred to are those of the Pottery Mechanics' Institute discussed later in this paper. Local newspapers for the 1820 contain only a few announcements of itinerent lecturers in science-perhaps three a
year.

6 Two earthenware manufacturers, three nonconforming ministers (one of whom was also a modeller of pottery), one printer, one attorney, and one physician.

7 Pottery Philosophical Society Minute-Book (unpaged), entry for 31 December 1819. The Minute-Book (hereafter cited as P.P.S. Minutes, with date of entry) is in the Library of the North Staffordshire Field Club in the Horace Barks Library. I should like to express my thanks to the Club for permission to quote from it.

8 P.P.S. Minutes, frontispiece. 
not due to any lack of order, or of local respectability, or, indeed, of ambition.

The Society's original plan called for weekly meetings. Alternate Friday evenings were to be devoted to 'a Lecture ... on some branch of Natural, Experimental, or Mental Philosophy'; intermediate Fridays 'to a discussion of such Philosophical Questions, and to the performance of such Philosophical Experiments, as shall have been first approved of [by the Committee]', providing that 'neither religious nor political questions shall be made the subject of any of the Lectures or Discussions in the Society'." Arrangements were made to rent rooms at ten pounds per year and for the collection of philosophical apparatus and the rudiments of a scientific library.

As the Philosophical Society was locally ambitious in its plans, so it was in the choice of a patron-Josiah Wedgwood jun. (1 769-1843), the second son of the great Wedgwood. ${ }^{10}$ The Wedgwoods were potters, but they were not as other potters. They were philosophers and gentlemen as well. Educated with his brothers, Tom ( $177 \mathrm{I}-\mathrm{I} 805$ ) and John (1 766-1 844), at the University of Edinburgh, and tutored at home in Etruria Hall by John Leslie (later Professor of Mathematics and of Natural Philosophy at Edinburgh), the young Josiah had in mind the life of a literary country gentleman rather than that of the progressive North Staffordshire potter. From 1793 to 1807 he resided at country houses in Surrey and Dorset, extending hospitality, and sometimes patronage, to a circle of liberal philosophers, poets and scientists including Coleridge, Wordsworth, Mackintosh, Francis Horner, Sydney Smith, Sir Joseph Banks, Humphry Davy and Thomas Beddoes. ${ }^{11}$ Only an alarming decline in the fortunes of the Etruria works near Hanley, then managed by his cousin, induced him to return to active

9 Ibid., 20 January 1820 , rules $10-13$. It will be evident from later discussion that the ban on religion referred, as it so often did in similar societies, to controversial religious topics only.

10 On the life of Josiah Wedgwood jun., see Eliza Meteyard, A Group of Englishmen (1795-1815): Being Records of the Younger Wedgwoods and Their Friends (London, $1871)$, esp. 180-88, and R. B. Litchfield, Tom Wedgwood: The First Photographer (London, 1903), esp. 41-43. Josiah jun. was one of the members of the Royal Institution in London, the first MP for Stoke after the passage of the Reform Bill, and the Chairman of the local Society for the Diffusion of Useful Knowledge. Historians of science know his name only as the kindly uncle of the young Charles Darwin who persuaded Darwin's father to allow the young naturalist to go aboard the Beagle. The eldest son, John, was one of the projectors of the Horticultural Society of Iondon and the youngest, Tom, had genuine scientific gifts and might have made important contributions to physics and philosophy had chronic illness not incapacitated him.

11 Additional details of the Wedgwood circle are interspersed through Joseph Cottle, Early Recollections of Samuel Taylor Coleridge (2 vols., London, 1837). 
participation in the business. Even then, he chose to live in a country house some distance from the works rather than in Etruria Hall.

Wedgwood's local stature rested on his name, his character, his wealth, his cultural contacts-and his religion, a Unitarian in a Methodist district. But the Josiah Wedgwood jun. who hosted and corresponded with Banks, Davy and Faraday was not overly anxious to participate in the Pottery Philosophical Society. After repeated requests to serve as its President, Wedgwood finally capitulated,

regretting at the same time that living at the distance of ten miles from the Society's rooms, and being much engaged, I cannot hope to be able to attend the meetings of the Society. And I take the liberty of mentioning this inability again to guard against the possibility of my appearing to be wanting in respect to a Society who have done me so much honour. ${ }^{12}$

Wedgwood was good to his word; except for the annual dinners of the Society during its first several years, he appears never to have attended its meetings, neglecting until reminded to pay his subscription to the Society for the years $182 \mathrm{I}$ to $\mathrm{I} 824 .^{13}$

In the effective absence of Josiah Wedgwood the dominant social tone of the Philosophical Society was set by a coterie of progressive masterpotters, of whom the outstanding examples were the brothers John ( 1785 I 860) and William Ridgway (1788-1864) - the sons of Job Ridgway (1759-1814), who had been the founder of the Methodist New Connexion in Hanley. ${ }^{14}$ Partners in the prosperous Cauldon Place pot-works, members of the Board of Governors of the Bethesda New Connexion Chapel in Hanley, and contributors to the New Connexion Magazine, the Ridgway brothers were at the centre of a wide range of local movements aiming at social and political reform. They were prime movers in the Society for the Prosecution of Felons, the Savings Bank, the British School, and agitated for

12 Letter from Josiah Wedgwood jun. to Thomas Mousley (Secretary of the Pottery Philosophical Society), I 7 January 1820 , MS. $E-23480-31$, in the possession of Messrs Josiah Wedgwood and Sons, Ltd. at Barlaston, Stoke-on-Trent. I should like to thank the Wedgwood Museum Trust for permission to use and quote from letters in the Wedgwood Papers.

13 Letter from the Rev Ridgway William Newland (Secretary of the Pottery Philosophical Society) to Josiah Wedgwood jun., 5 January 1824 , MS. E-23507-31, Wedgwood Papers, Barlaston.

14 For information on the Ridgways see: Hilary Stickels, The Contribution of John Ridgway and the Methodist New Connexion to the Urban Development of Hanley (Typescript Finals Dissertation, University of Keele, I97I) [In Horace Barks Library]; A. Shelley, The Ridgways (Typescript Extension Thesis, University of Keele, 1971) [In Library of the Institute of Education, University of Keele]; J. Stacey, A Prince in Israel: Sketches of the Life of John Ridgway (London, 1862). 
Parliamentary reform and acts for municipal police and lighting. One of the two local newspapers in the 1820 , the liberal Pottery Mercury, was apparently their house-organ-its editorial policy expressing the outlook of John Ridgway who was said to have been 'for nearly forty years ... the chief political force in the borough of Stoke-on-Trent'. ${ }^{15}$ To their political opponents the Ridgways and their associates were 'the Radical Saints of Hanley'. ${ }^{16}$

Many of the most prestigious and active members of the Pottery Philosophical Society were associates of the Ridgways and adherents of the local Methodist New Connexion. Like Primitive Methodism the New Connexion had its origin in North Staffordshire and flourished there as nowhere else. From its beginnings in 1798 the New Connexion grew to count 20,484 members in England by $1840-2,304$ of whom resided within the Hanley and Longton circuits. ${ }^{17}$ Born out of a revolt against the conservative tendencies of the parent Wesleyan chapel, the Potteries' New Connexion served the area's progressive middle classes and attracted epithets like 'revolutionary' and 'Jacobin'. ${ }^{18}$ But, although the Potteries' New Connexion was most definitely liberal in political outlook, neither it nor its leaders can sensibly be regarded as radical. John Ridgway disliked practical, if not philosophical, radicalism, feared the mob, and made every effort to insure that the changes he advocated were moderate and carried out in an orderly manner. Potters and professionals attended the New Connexion chapel, while the lower orders made up the congregations of the Primitive and Wesleyan Methodists. The Pottery Philosophical Society recruited largely from the New Connexion.

The peculiarly Methodist view of knowledge and education has been discussed adequately elsewhere. ${ }^{19}$ Intellectual inquiry for its own sake was

15 Stickels, op. cit. note 14,6 .

16 Pottery Mercury, 16 March 1825 [In the William Salt Library, Stafford.] The Ridgways' involvement with the Pottery Mercury was apparently the occasion for the only instance of political conflict in the Society. Two other members of the Philosophical Society, besides the Ridgways, were connected with editing the Mercury (founded in 1824)-Thomas Allbut and Leonard James Abington. The liberal Mercury had been set up in opposition to the Pottery Gazette (founded 1822), edited by Society member James Amphlette. The Gazette was understood to be a 'High Church and Ultra Tory paper'. In I825 the Ridgways brought a libel suit against Amphlette for articles implying that they were politically subversive. Amphlette, upon being convicted, resigned from the Society.

17 John Ward, The Borough of Stoke-upon-Trent (London, 1843), 400.

18 Ibid., 399, and Stickels, op. cit. note $14,7$.

$\rightarrow$ Robert E. Schofield, 'John Wesley and Science in Eighteenth-Century England'. Isis, 44 (1953), 33I-40, and Stuart Andrews, Methodism and Society (London, 1970), $54-60$, and 118 where J. H. Plumb is quoted to the effect that 'there was nothing intellectual about Methodism; the rational attitude, the most fashionable intellectual attitude of the day, was absolutely absent'. 
discouraged but the 'acquisition of useful knowledge could be seen as godly and full of merit. ... Science-botany, biology, geology, chemistry, mathematics, and, in particular, the applied sciences-the Methodists looked upon with favour'. ${ }^{20}$ In this the Potteries' New Connexion (and the Philosophical Society) was no exception to the general thrust of Methodism. There were three major impulses contained in the local New Connexion's attitude towards the pursuit of natural knowledge: it might ward off the pernicious decay of the higher faculties through idleness, it might tend towards practical use, and it certainly would serve to illustrate the beneficence of the Creator. These strains are reflected in an i8rg essay by a local member of the New Connexion on 'The Advantages of Social Meetings for Promoting Literary Improvement' : ${ }^{21}$

If it be the duty of man, by every lawful means to preserve the health, and increase the vigour of his body; it must likewise be a duty, as much more obligatory, as the mind is more exalted and more valuable, to employ every means of information and exercise, to preserve the vigour of its powers... [rather than by idleness] to suffer that heavenly soil, which by proper culture and attention, would produce the happiest and most useful fruits, to be sterile and unproductive, or productive only of the wild brambles of error and vice.... By the proper knowledge of philosophy and science, he may improve his worldly circumstances, and obtain riches and honour; he may pleasantly occupy his thoughts; employ in innocent researches, or in useful contrivances, that time, which might otherwise be appropriated to vicious pursuits....

But religious knowledge, one important form of which was natural theology, was higher and more noble, promoting spiritual interests beside which 'bodily ease and worldly riches [derived from the cultivation of science and philosophy] are nothing, less than nothing or vanity.'

The moral aspects of the study of science were as evident to members of the Pottery Philosophical Society as the utilitarian. One of them, a Hanley printer and New Connexion Methodist named Thomas Allbut (1777I 857), wrote Elements of Useful Knowledge for the instruction of children in dialogue form. ${ }^{22}$ At the conclusion of the section on 'Natural Philosophy' he asked, 'What may be learnt from the foregoing remarks? - That in the whole course of nature nothing comes by chance, but is produced by some

20 E. P. Thompson, The Making of the English Working Class (Harmondsworth: Penguin 1968), 8 I 2.

21 'A.', The New Methodist Magazine, 22 (1819), 26-9, 112-16, 147-51 (26-7, I12) [Horace Barks Library].

22 T[homas] Allbut, Elements of Useful Knowledge, drawn up for the use of children in questions and answers, $15^{\text {th }}$ edn. (Hanley, 1835 ). 
cause; and that there must be a Great First Gause-which is God himself. The visible creation may be considered, as intended every moment to present to our view the increasing energies of $\mathrm{Him}$, in whom we live and move. ${ }^{23}$ Similarly, the cultivation of science might be of more mundane utility. Question-'Is the science of Geology of real utility?' Answer-

The knowledge of geology is of the greatest use to persons whose interest it is to dig in the earth for springs, for building-stones, coals, or metals; as a proper knowledge of it would direct them in their work, and often save much needless expense of money and labour. It is also of use to every man, as it displays the wonderful and beneficent arrangement of materials for the service of the human race... [placing] the minerals in such order as to supply the wants, while they excite and reward the industry of man. ${ }^{24}$

It is clear from the above and similar statements that the natural theological justification for the pursuit of science was inextricably intertwined with the practical utilitarian argument. Through science God and Mammon might be worshipped at the same altar. The study and propagation of scientific knowledge as the praise of God, as practically useful knowledge, as the cultural self-expression of a progressive industrial class, as an anodyne for temptation and turbulence-all these themes may be observed in the career of the Pottery Philosophical Society.

As the Society began functioning it became apparent that its primary institutional purpose was the provision of adult education suitable for the middle classes of the Potteries. The fortnightly lectures were treated seriously, even earnestly. All lectures were to be given by members of the Society and expenses incurred in their preparation could be defrayed up to the value of ro/6d, or more by permission of the Committee. Tables and chairs were bought, 250 tickets for the admission of non-members printed, and a magic lantern ordered for demonstrations. Through the first nine months of 1820 members gave lectures illustrating the Society's concern with cultural selfimprovement and with the utilitarian and natural theological functions of science-'The Use and Application of Chemistry to the Arts and Manufactures', 'The History and Advantages of Philosophy', 'The Analysis of Clay', 'The Structure of the Universe'-this last by a Baptist minister intent on proving the plurality of worlds. By July 1820 affairs were going on so well that a decision was taken to appoint one of the members as standing lecturer. William Henley, who was probably some sort of practical 
chemist, was commissioned 'to deliver twelve lectures in each year, and an extra lecture whenever there may be no other member of the Society willing to perform that task. ${ }^{25}$ For these services he was to be paid the generous sum of twenty guineas a year. Henley's lectureship did not last long. In June I $82 \mathrm{I}$ it was decided that in consequence of the depressed state of the Society's finances, it was inexpedient to continue any longer to pay a salary to the standing Lecturer', although the members wished it understood that they remained 'perfectly satisfied' with Henley's performance. ${ }^{26}$

In addition to this abortive attempt to sustain a professional lectureship, the first year of the Society's existence had witnessed a division of labour within its ranks - one which corresponded to social divisions. Of the twentyfour lectures actually given to meetings of the Society during I 820 , at most one was delivered by a manufacturer. The remainder were the work of a small circle of medical men and ministers. Nine had been given by the paid lecturer, two by a Hanley surgeon ('The Anatomy of the Eye', 'The Nutrition and Renovation of the Human Body'), two by the attorney ('On Light, Heat and Colours'), and the remainder by three nonconforming ministers (e.g., 'On Some of the Presumed Causes and Effects of the General Deluge'). The role of the pottery manufacturers was largely the suggestion of topics for the discussions, many of which intended to relate science to the manufacture of ceramics. Beyond that, the manufacturers served mainly to provide an attentive, locally elite audience for the scientific performances of medical men and ministers. The Pottery Philosophical Society was to prosper as long as the potters saw advantage in listening and the medical men and ministers in performing.

The first Annual Report, read at the Anniversary Dinner and Meeting chaired by Josiah Wedgwood, indicated that the members were well pleased with the Society's proceedings thus far. While calling attention to

those interesting and useful Papers with which the Society has been presented ... the Committee at the same time indulges the hope that the objects for which the Society was instituted have been kept steadily in view - that a watchful attention has been paid to the interests of religion and of virtue as well as of Literature and Science. ${ }^{27}$

Renewed support was solicited for

an Institution founded on the beneficent Principles of promulgating the general

25 P.P.S. Minutes (10 July 1 820).

26 Ibid. (7 June 1821 ).

27 Ibid. (4 January 1821 ). 
doctrines of Science, of elucidating their application to the various arts subservient to our pleasures, or our wants, and of promoting the true interests of Religion and of Virtue.

The Philosophical Society was particularly proud of the lectures delivered by Mr Henley on 'theoretical and practical Chemistry',

the utility of which will be apparent to the Sóciety when we state that the whole of the processes adopted in the manufacture of Earthenware are entirely dependent on the action of Chemical Laws for their successful result....

Many of the other scientific lectures had been given by Leonard James Abington (1 785-1867), a modeller of pots, nonconforming minister and newspaper editor who had come to the Potteries from London several years previously. ${ }^{28}$ In Abington the impulses of science as natural theology and as useful knowledge were intricately combined. His intellectual interests ranged widely; to the Philosophical Society and to other less formal local audiences he lectured on geology, mineralogy, metallurgy, conchology, entomology, chemistry, astronomy, heraldry, pottery, the chemistry of pottery, Egyptian antiquities, meteorology, and (pausing for a breath) revealed religion. ${ }^{29}$ His religion was resilient enough to absorb the new geological theories of Hutton and Lyell-and to emerge the stronger. $\mathrm{He}$ was, according to his biographer,

among the earliest who embraced the startling theories propounded by the modern School of Geologists. While many good and able men trembled for the safety of the Ark of God, and shuddered lest the facts Geology was unfolding should conflict with the Mosaic Record, he looked calmly on, reposing in the assurance that the investigations of Science would strengthen rather than weaken the evidence of its Inspiration. From this steadfast conviction he never swerved, and lived to see his fond anticipations fully realized. ${ }^{30}$

As a lecturer to the Philosophical Society Abington's 'rule was to make himself fully master of his subject' (whatever it was on the occasion), which ability, 'combined with a happy mode of imparting information to others,

28 Personal Recollections of the late Leonard James Abington, of Hanley, Staffordshire; with Memoir and Extracts from his Correspondence (Hanley, I 868).

29 Ibid., 10.

30 Ibid., 12. But it is not clear that Abington did in fact maintain his calm in the face of new developments until the end of his life. In 1867 he was pleased to send his grandson, another budding geologist, a paper by Esau Hopkins which 'annihilates the infidel theory or Nebular hypothesis, and shows that the whole is a fallacy, and that the world had its origin in water and not in fire. . . Geologists are giving up Pluto, and going back to Neptune again... . The proud scoffers at Moses, after worshipping at the shrine of Geology, are fain to come back to Moses again.' (Ibid., 128.) 
rendered his style particularly attractive'. ${ }^{31}$ Certainly, the Society's first Annual Report reflected its appreciation and Abington's effectiveness in imparting the 'general doctrines of Science'. His botanical lecture, for example, showed

that the infinite variety of forms, colours and odours observed in flowers, and which are generally considered as diversified by the Creator for the pleasure and gratification of man, have also higher purposes of utility, and that the most minute of these circumstances have an inseparable connexion with the great concern of fructification.

\section{Through his geological series}

on some presumed causes and effects of the General Deluge, the doctrines of some modern geologists were explained, and the insufficiency of the data on which they are founded was shewn.... The Mosaic Account of the Deluge was considered confirmed by the shape of our Continents.... The recent date of the catastrophe proved by the formation of fluviatile lands, the disintegration of mountains, and other natural chronometers. Objections arising from the discoveries and theories of the latest Geological Writers were in the conclu. sion stated and examined.

Yet, in spite of the Philosophical Society's apparently impeccable theological stance, its second Annual Report, submitted on 4 January 1822, manifested a marked defensiveness about the implications of science for religion and the political order. 'The Committee is aware,' the Report noted,

that it has frequently been objected against Societies of this description, that they tend to the dissemination of free-thinking and irreligious principles; but such sweeping denunciations as frequently indicate the malevolence of the speaker as the justice of his sentiments. The Committee is ready to acknowledge that serious injuries have emanated ere now from Societies miscalled Philosophical ...32

The Pottery Philosophical Society, it was to be understood, was emphatically not of this kind. ${ }^{33}$ 'All noxious and party questions' had been rigorously excluded, and no paper had been read or topic discussed 'which can by possibility militate against the interest either of religion, of virtue, or of truth.'

31 Ibid., 13.

32 P.P.S. Minutes (4 January 1822 ).

33 I have not been able to discover any particular local incident which might have given rise to this defensiveness about the implications of science. 
Whatever other Societies may have been [the Report continued] this Institution is the friend of what is honorable and virtuous, respectable and good. Upon this proud eminence it erects its Standard, and its banners bear the appropriate inscriptions The Cause of Religion and of Good Order and of Truth.

Since the Society thus demonstrated its awareness of the problems which other provincial scientific institutions had encountered, it comes as no surprise that they were also aware of their own probable position in the social hierarchy of such organizations. They were at once realistic and sanguine about the role they might play in the 'March of Intellect' :

Perhaps it may be said that the Society has not sufficient weight and importance to entitle it to countenance and patronage. 'Tis true the Society does not enumerate Princes and Nobles amongst its members or enroll the names of thousands in its list. Yet its cause is good tho' its means are limited. [We look forward to] holding out a helping hand to larger Institutions engaged in the same useful labours. The little brook which flows in silence down the valley may serve to swell the stream of the mighty river which sheds prosperity and wealth over kingdoms. ${ }^{34}$

Recognizing that its local elite counted for little in Royal Society terms, the members yet hoped that in the 'Republic of Science' all men might be equal and all might participate on the same terms, to the same utilitarian end. But in the strictly local sense, utility might mean particular utility to the perceived needs of the earthenware and china manufacturers. The continuing patronage of the manufacturers ensured that the attentions of the intellectually active members of the Society would be directed, at least occasionally, to scientific topics of seeming relation to the staple manufacture.

Of the seventy-two men (and one woman) elected to the Pottery Philosophical Society during its entire existence, twenty-four owned pot-works and another eight were directly involved in the manufacture of ceramics. There were nine merchants of other types, eight medical men (only one of whom held an MD at the time of membership), six ministers, ${ }^{35}$ three attorneys, two gentlemen, and the remainder of miscellaneous occupation or unidentifiable. ${ }^{36}$ The only printed membership list discovered, that for

34 P.P.S. Minutes (4 January 1822 ).

35 Only one of the ministers was Church of England; he was admitted late in the Society's career and there is no evidence that he ever took part in the Society's proceedings.

36 Identification of these, for the most part, very obscure men has relied on local directories of which the most useful has been Thomas Allbut's Newcastle and Pottery General Commercial Directory, for 1822-3. Also of value have been Rupert Simms' Bibliotheca Staffordiensis (Lichfield, 1894) and the collection of local newspapers in the William Salt Library, Stafford. 
December 1824 , reveals a composition roughly similar to the overall figures. ${ }^{37}$ At that time potters, engravers, modellers and manufacturers of glaze colours made up fifteen of the total of twenty-seven members, with ministers and medical men constituting another five.

Although the medical men were a dominant factor in the Society's scientific proceedings, it is perhaps surprising that the most prestigious group of physicians and surgeons in the district was unrepresented. The nearby North Staffordshire Infirmary was founded in 1802 but none of its resident medical staff ever became members of the Philosophical Society. ${ }^{38}$ This is a situation totally unlike that of the Manchester Literary and Philosophical Society in which the medical staff of the Manchester Infirmary were prime movers in establishing the Society and were heavily represented in the original membership. ${ }^{39}$ One would think that the cultural requirements of universityeducated medical men, tending towards the scientific, might have attracted them to the Philosophical Society. But here one must consider both the social standing of the Society and the control of the Infirmary. Since it is evident that Josiah Wedgwood jun., as a leading officer of the North Staffordshire Infirmary, took a very large share in the selection of physicians and surgeons, it is probable that they gravitated to his intellectual circle at Maer Hall (south of Newcastle-under-Lyme) rather than to the lesser society of the Potteries.

However committed the master-potters were to applied science as economically useful knowledge, there is no evidence at all that the Pottery Philosophical Society undertook or supported cooperative scientific research on ceramics, nor that they regarded original research per se to be an integral part of the organization's purpose. ${ }^{40}$ Science was considered to be of substantial local utility to its audience of ceramic manufacturers even if they only absorbed some general scientific principles, technical information and

37 See list printed in the Pottery Mercury (22 December 1824).

38 A list of the resident medical staff is in Ralph Hordley, $A$ Concise History of the Rise and Progress of the North Staffordshire Infirmary and Eye Hospital from 1802 to 1902 (Newcastle [-under-Lyme], 1902), 59-69.

39 Thackray, op. cit. note $\mathrm{I}$.

40 It may, however, be of interest that one of the central research problems connected with the pottery manufacture in the early nineteenth century was the development of a leadless glaze, and that the three local figures most closely associated with this research were members of the Philosophical Society-Job Meigh (who won a gold medal from the Society of Arts in 1822), John Ridgway and Ralph Stevenson. See R. G. Haggar, 'Pottery', Victoria County History: Stafford, II (1967), 63. There was some tradition of cooperative research to solve ceramic technology problems in North Staffordshire. See

$\rightarrow$ Robert E. Schofield, 'Josiah Wedgwood and a Proposed Eighteenth-Century Industrial Research Organization', Isis, 47 (1956), I6-1 9. 
innovative attitudes. Once the Society had succeeded in creating a certain level of technical awareness and scientific consciousness, the progressive manufacturers might take it from there, encouraging experimentation and innovation in their own works if they were so inclined.

One of the most valuable aids to this creation of technical and scientific awareness was a library. As early as ${ }_{1} 8_{2} \mathrm{I}$ it became evident that the Philosophical Society was employing a substantial portion of its limited resources in subscriptions to a number of scientific periodicals. The Annals of Philosophy was taken until 1824 , when it was discontinued in favour of Brewster's Edinburgh Journal of Science. During the course of its existence the Society also took numbers of the Edinburgh Philosophical Journal and the Edinburgh New Philosophical Journal, the Journal of the Royal Institution, Rennie's Field Naturalist, Loudon's Magazine of Natural History, and about eleven other titles. The Society was the sole local source for these journals and they were circulated among the members according to distance from the Society's rooms. Through the I 820 os there was a distinct decline in subscriptions to technological and 'exact science' periodicals in favour of those dealing primarily with natural history.

Early in 1823 it was decided to make an attempt to develop a serious scientific and technical library which might serve the entire trade and professional community of the Potteries. The Society's Committee resolved 'that a Library be established entitled the Literary and Scientific Library from which Novels, Dramatic Writings, and Poetry shall be excluded'. ${ }^{41}$ From that time on all prospective members of the Philosophical Society had also to become subscribers to the Library at one guinea per year, but persons might subscribe to the Library without becoming members of the Society. In addition, the Society had been making a considerable investment in the purchase of scientific apparatus and natural history objects. A collection of minerals had been bought from Mr Henley, and ten pounds expended for a cabinet to house the collection; twelve guineas had been laid out for an air-pump, five pounds for other apparatus, and an unknown amount for 'an electrical machine'.

In spite of these signs of apparent entrepreneurial energy, the Philosophical Society had already begun losing its momentum and was scraping the bottom of its financial resources scarcely a year and a half after it had been founded. The twenty-four lectures given in 1820 dwindled to fifteen in $182 \mathrm{I}$, twelve in 1822 , eleven in 1823 , and eight in 1824 . Division between 
performing medical men and ministers and the manufacturers in the audience had produced an effect on morale. The energies and capabilities of the local surgeons and preachers were inadequate to sustain the Society on that plan indefinitely. Technological ambition and aspiration alone, without demonstrable result, was unsatisfactory. Meetings became less frequent and 'conversations' or 'discussions' on topics most commonly suggested by the master-potters took the place of scientific lectures. The discussion topics were often non-scientific and sometimes apparently frivolous-'Will judicial Astrology admit of Defence?', 'On Ancient Pagan Oracles'-but they were possibly more attractive and entertaining to the membership than the more strictly scientific lectures of the past. Attendance by outsiders was solicited; tickets for a quarter's lectures could be purchased at the bookseller's for three shillings and sixpence.

But by the middle of 1822 it became clear that the Society could no longer maintain its rented rooms; it settled accounts with the landlord and moved into accommodation provided by the British School in Shelton, a number of whose Governors were also members of the Philosophical Society. The use of the British School's rooms was apparently extended gratis and the Society's Library was lodged in the same place. Despite these economy measures the arrears of members' subscriptions was beginning to cause problems. Towards the end of 1825 the financial situation became especially serious (for reasons to be discussed later) and a number of resignations were handed in, including those of medical men, ministers and manufacturers. Josiah Wedgwood now ceased serving even as figure-head President.

The Society met only once in $1826^{42}$ and on 14 July 1827 a special general meeting was held to reorganize the Philosophical Society along completely different lines. 'Various untoward circumstances having occurred [in the past year and a half] to cramp the operations of the Society', it was nonetheless decided to try to continue. The old rules were suspended and it was resolved to meet only every third week, no longer at the British School, but at the homes of each of the members in rotation. There was, in future, to be no fixed annual subscription but only an assessment equal to each member's share of expenses actually incurred. By the $18_{3}$ os this amounted to only four or five shillings a year. The Society's property was

42 Although the Pottery Mercury of 27 September 1826 contains a schedule for a lecture-series in the Society, the Minute-Book does not record that they were delivered. Indeed, entries in the Minute-Book after 1827 are few and uninformative. 
gradually either disposed of or returned to the members who had donated it.

On this much reduced plan the Philosophical Society continued for several years. Lectures were no longer given, the members now chatting agreeably and scientifically over coffee and port. The social tone of the group remained as high as it ever was; it was during the Society's last years that an Anglican clergyman and a Cambridge-educated landowner were admitted to its ranks. The cultivation of science was now less formal and less rigorous, although, in a sense, not less serious. The circulation of scientific periodicals remained the Society's single most important institutional function, and even expanded during this period. Yet however loose the organization seems to have become, it is clear that the members continued to regard themselves as very important in local terms and still thought of science as an integral element in the cultural self-expression of their class. The Annual Report submitted on 7 January 1830 , long after the Philosophical Society had contracted to a peripatetic discussion-group, provides the clearest and most forceful summation of the members' image of science and its cultural significance.

Ever since reorganization the Society, so it claimed, had been 'going on prosperously'. 'The conversations ... being conducted in a pleasing, and familiar form, devoid of technicality and pedantry, are at once interesting and amusing'. The Society's technical aspirations had seemingly been replaced by a stronger dose of science as rational amusement, social sermon and class-identification. The subscriptions to scientific periodicals, for example, 'afford to contemplative minds, opportunities for improvement, which has always been the aim and desire of the Society. To say that Societies of this kind are not useful would be to say that simple powers are equivalent to a number of the same powers concentrated and directed to the same object, which all experience teaches us to be absurd.' Science also served to identify progressive elements in society; the seventeenth-century distinction between the Ancients and the Moderns was revived to indicate that the Ancients are always with us :

It is by association that Man improves in all situations, and the human mind is most powerfully assisted in its pursuits by communications with those of a kindred nature. If it were necessary to illustrate, what greater example have we of this than in the great national Institute of France, and the Royal Society of this Country. Minds which indolence might have kept bound down in the chains of apathy have been roused like the Sleeping Lion to feats [of] which in its solitary nature it deemed itself incapable.... Is it not by the vast accumulation of intelligence increasing as time rolls on that the Moderns have so far 
improved upon the Antients as to make the Water and the Air subservient to their meanest wishes?... It is, therefore, hoped that the Members of this Society... will each succeeding year feel additional interest in its meetings, and that, with the bright examples of the brilliant results of similar societies, they will, consistently with their other avocations, lay their shoulders to the work, and aid in the 'March of Intellect'.

Still, the theological aspect of science as cultural pursuit had to be separately emphasized. 'Our Society,' its Secretary wrote,

is not simply to be viewed in a scientific or philosophical point, it also is of considerable moral importance; for altho' religion, as a subject of discourse, is precluded by its rules, it is submitted that the tendency of its conversations have all been to elevate the creature, and, upon proper, and christian, principles, to examine those works which lead us from 'nature up to nature's God.'

Five years after this confident credo of the nineteenth-century scientific amateur the Minute-Book of the Pottery Philosophical Society abruptly ends, giving no clue as to the immediate cause of its final demise. But, as a formal scientific institution, the Society had been moribund for perhaps eight years. Irrevocable decline set in when the Society's proceedings lost a measure of their cultural appeal to a rival institution-the Pottery Mechanics' Institute.

The first signs of interest in establishing a Mechanics' Institute in the Potteries appeared in mid-I $825{ }^{43}$ The writer of a letter to the editor of the Pottery Mercury, taking note of institutions for the education of the working classes founded elsewhere, complained that 'we in the Potteries seem almost last in the race of intellectual glory; we have, at present, no institution that applies itself to the wants of the labouring classes among us'. Present scientific organizations did not answer the acute local need:

The remarks I am about to make on our existing institutions do not arise from any want of respect to them, but from a conviction of a want of practical utility to the classes for which I am pleading. The present Philosophical Society is too exclusive in its system, owing to its subscription being perhaps too high; the want of the key-stone in the arch, a good library, and of that fundamental rule which has been found so efficacious in most cases, that the Committee of management shall consist of at least two-thirds working men. The Pottery

43 On Mechanics' Institutes in general see Mable Tylecote, The Mechanics' Institutes of Lancashire and Yorkshire before 1851 (Manchester, 1957) and Thomas Kelly, 1 History of Adult Education in Great Britain, 2nd edn. (Liverpool, 1970), ch. viii. 
Library ${ }^{44}$ is not at all available to the lower classes, and to very few of the middling classes.... 45

Science as useful knowledge now appeared in a stronger light with reference to the lower classes. An informed artisan class, it was felt, might produce more economic benefit than a scientifically aware entrepreneurial class in the Potteries. This shift in the social locus of the utilitarian justification for science was attended, throughout Britain, by a certain amount of institutional conflict between existing middle-class scientific societies and the newly established Mechanics' Institutes of the 1820 and 1830 . Advocates of the dissemination of science to the workers regarded the middle-class organizations as the reflection of an idea past its time. The differences between the two types of organizations were pointed out by a mid-century champion of the Mechanics' Institutes :

The Provincial Philosophical Societies of England have completed their career, they are the debris of an age passed away. Originally formed upon the contracted basis of improving rather than diffusing or popularizing the truths of science, - of cultivating instead of disseminating knowledge, they have continued as aristocratic assemblies, philosophers by the length of their purses, and worldly condition enabling them to comply with the forms and terms of membership. Many of these societies are now held together by little coffee parties ... while their outward signs of vitality are exhibited in an occasional course of lectures, which can scarcely vie with the programme of the humbler [Mechanics'] Institutes. ${ }^{46}$

The distinction argued here between science as (at least potential) research and science as a body of facts, principles and attitudes which might be systematically inculcated did not, of course, correspond exactly to the differences between the Pottery Philosophical Society and the proposed Mechanics' Institute. But it is apparent that there was initial conflict between them and that social divisions corresponded to a split in the perceived cultural uses of science.

44 This probably refers to a lending library run by the printer Thomas Allbut which had been founded in the late 1790 . The statement also indicates that the Society's library had not achieved a local reputation.

45 'Philo', 'Observations on the Utility of forming Societies in the Potteries, for the Improvement of the Working Classes', Pottery Mercury, 22 June 1825 . Note the confusion in the writer's mind between the management of Mechanics' Institutes and that of the Philosophical Societies.

46 Hudson, $o p$. cit. note 1,167 . It ought to be emphasized that, while the rhetoric attached to the Mechanics' Institutes was largely concerned with the working class, middle-class participation in their founding and control was extensive. In many instances clerks, shop-keepers and tradesmen made up the bulk of the audience. 
As the middle-class projectors of the Pottery Mechanics' Institute viewed the matter, science for the workers might serve two distinct and beneficial purposes; science was practically useful knowledge and science was a suitable anodyne for sensuality and social disruption (both counter-productive tendencies in a smoothly functioning industrial society). Although both these uses of science were also observed in the middle-class Philosophical Society, they were to be given emphasis and a different form in the proposed Mechanics' Institute. Practical utility remained a crucial justification for the cultivation of science, but it was now argued that economic benefit might flow more readily from a scientifically and technically informed working class than from the scientific involvement of its employers. 'The business of no district is more intimately connected with science and art than those pursued here', it was claimed, but it would be 'from the improvement in the minds and habits of the working classes, the muscles and sinews of society, that any real and permanent improvement may be expected in these districts' ${ }^{47}$ It was the scientific education of the man at the potter's wheel that would produce profit, not the innocent recreation of the owner of the wheel :

... there is no science of so much value to a Potter as Chemistry; and yet how few of our people are even imperfectly acquainted with it.... Whatever the practical potter may think, it really is a disgrace to him to be ignorant of this science. ... An extended knowledge of [chemistry] would enable him to detect any impurities or adulterations in his materials, to reject such as were unfit, and would suggest to him also new and superior combinations ... sparing him the trouble and expense of absurd experiments. ${ }^{48}$

And so the utilitarian argument for workers' science went-embracing the study of geometry (in order to help them perceive 'that beauty and form are derived from a few geometrical figures') and anatomy (especially useful, it was said, for artists and modellers of pottery). It should be strongly emphasized that it is not a matter of concern here whether such justifications were entirely ingenuous or, indeed, whether workers' science in this form ever amounted to anything of measurable economic benefit to employers. The point at issue is that such arguments did succeed in mobilizing very considerable local support. The power of the concept in the Potteries

47 Pottery Mercury (22 June 1825 ).

48 'Patriot', letter to the editor of the Pottery Mercury (1 2 October 1825). However, it should be realized that that employed 'practical potter' only rarely had significant control over the processes of production in which he was engaged. 
probably had very little to do with practical utility in any sense which can now be assessed by the techniques of the economic historian.

Equally as important as the utilitarian justification was a subtle and complex defence of workers' science as social anodyne. In the face of vehement objections that the exposure of the 'simple' classes to the 'French philosophy' of Lavoisier and Laplace would run the risk of importing French social consequences, ${ }^{49}$ it was concluded that

the benefit arising [from scientific education of] workmen will be incalculable,by improving the intellect, and encouraging thought, it will raise them in the moral scale of society;--by studying the properties of matter, and the laws of nature, it will lead them to reverence their God, on viewing scientifically his wonderful works; and in consequence, by employing the mind that was before spent in frivolity and idleness, it will render them better husbands, fathers, and brothers. ${ }^{50}$

- and better workers. An industrial order which had a considerable stake in regularity and social stability was receptive to ideas which might tend to reinforce corresponding cultural values and attitudes in its workers.

The prevailing middle-class view was that workers' leisure was almost totally given over to carouse and sensual dissipation which rendered them less fit for the efficient performance of their duties. It was a view which was clearly reflected in the middle-class arguments for workers' science,

To extend the knowledge of science [is] the proposed object of Mechanics' Institutes.... Will it not be a source of innocent pleasure ... and an advantage to the public? Will it not tend to lessen their relish for those low and sensual pursuits which most deeply degrade the human character, and are most productive of domestic misery...? 51

Mechanics' Institutes would serve to 'extract [workers] from the tavern, the prize-ring, and the cock-pit'. Properly managed, with library books carefully selected, there was no danger that they 'will be converted into political fraternities for the nourishment and propagation of radicalism'. By close

49 The argument was not that the new French science was false but that it might lend itself to pernicious social metaphors. A very perceptive letter-writer observed that 'Know. ledge, as it respects vice and virtue, is neutral, and ... it depends on the quality of the ground on which it is thrown, whether it nourishes the wholesome fruit or concocts the deadly poison'. ('Caveat', in the Pottery Mercury, 12 October 1825.)

50 'A Mechanic', letter to the editor of the Pottery Mercury (13 July 1825). The writer was not necessarily in fact a 'mechanic'; middle-class advocates of the Institutes frequently adopted this guise to make their arguments weightier.

51 Rev. T. Allin, Pottery Mercury (22 February 1826). 
attention to the lessons of natural law and order, scientific instruction might have the praiseworthy effect of making workers 'good citizens, and teach [ing] them the nature and extent of their duties'. ${ }^{52}$ 'It appears then,' an advocate concluded, 'that the pursuit of knowledge is advantageous to the working man, by rendering him superior to habits of drinking, [and] by introducing him to new and purer pleasures, and all without any necessary ill consequences to his superiors. ${ }^{53}$ The temperance arguments especially counted for much in a district preoccupied with crime, violence, public drunkenness and a general lack of cultural tone. Thus, the morally analgesic function of science for the middle-class amateur seems to have been cast primarily as a matter of individual decision and self-improvement; science for the working class was a matter of collective social concern and would ideally produce class effects. But the arguments of utility and of social morality must be regarded as organically inter-related. Had there not been the hope of economic benefit from workers' science, it is doubtful that its potential as anodyne would have been an efficient justification.

The supporters of a Pottery Mechanics' Institute prevailed, succeeding perhaps beyond their expectations. ${ }^{54}$ The founding meeting was held in Hanley on 2 January I 826 -at the same inn where the Philosophical Society had been projected six years before. Josiah Wedgwood jun. was in the Chair, and this time he was far more than a mere figurehead. The idea of a Mechanics' Institute caught his imagination as the idea of middle-class science for the manufacturer-amateur had not. He readily subscribed one hundred guineas to the new project where previously he had begrudged four guineas to the Philosophical Society, ${ }^{55}$ and he actively solicited support for it among the local gentry. ${ }^{56}$ On the Committee formed to establish the Institute, or attending the original meeting, were many of the ministers, physicians, surgeons, and master-potters whose names had also been on the Philosophical Society's rolls. Some of them immediately resigned membership in the Philosophical Society.

One of the factors draining interest away from the middle-class Society

52 'Caveat', Pottery Mercury (2 I September 1825 ).

53 Letter to editor of the Pottery Mercury (28 September 1825).

54 R. A. Lowe, 'The Mechanics' Institutions of the Potteries', North Staffordshire Journal of Field Studies, 10 (1970), 75-82.

55 Ward, op. cit. note 17,393 n.

56 For example, W. Sneyd to Josiah Wedgwood jun. (2 December 1825) (MS. E-2612-3, Wedgwood Papers, deposited in the Keele University Library). Sneyd was reluctant to support the Mechanics' Institute, mainly owing to fear of dangerous social consequences, 'but having your .... sanction, I take for granted that it cannot be objectionable'. 
was the heavy capitalization of the new Mechanics' Institute. The Marquess of Stafford, later first Duke of Sutherland, contributed two hundred pounds at the outset and considerable sums were pledged by members of the local aristocracy and gentry who had had nothing to do with the Philosophical Society. Within a year the Mechanics' Institute had amassed a substantial library, containing I,500 volumes and particularly strong in the areas of chemistry, geology and mathematics. ${ }^{57}$ By 1835 it had moved to a new building, costing six hundred pounds and containing lecture-rooms, classrooms, library, laboratory, and, eventually, a museum.

If the Mechanics' Institute affected the Philosophical Society's morale and detracted from its utilitarian public image, its most telling blow lay in the Institute's superior attractiveness to the ministers and medical men who had formed the class of scientific performers before the Society. On I I November I 825 the members of the Philosophical Society proposed to discuss the topic 'Would an Introduction to a Knowledge of the Arts and Sciences be Hurtful or Beneficial to Society in General?'. Obviously, at least some of them decided that it would in fact be beneficial. Very soon, medical men and ministers who had been active members of the Philosophical Society began to deliver scientific lectures at the Mechanics' Institute. ${ }^{58}$ The audience at the new organization was bigger and, paradoxically, more prestigious (see note 46 ); the resources were more extensive, the rewards more generous - the early lecturers were paid, although it is not known how much. By 1826 lectures were no longer given at the Philosophical Society at all and, while the Mechanics' Institute flourished, irrevocable decline had begun in the forum for middle-class science in the Potteries.

The failure of the Pottery Philosophical Society was a failure in its own terms, of its own ambitions. It is essentially uninteresting to distribute praise and blame according to latter-day standards of the scientific community or of scientific 'professionalism' and such has not been the purpose of this case-study. The aim has rather been to use the strikingly candid records of the Society to illuminate certain locally-shared images of science and of what might be accomplished through science. There ought to be no defensiveness about the historical importance of such contemporary images of science; they may be at least as significant for the understanding of the

57 Ward, op. cit. note 17, 393; Pottery Mechanics' Institution. Library Rules and Catalogue of Books (Burslem, 1827) [Horace Barks Library].

$58 \mathrm{~A}$ list of lectures given at the Institute is in James Broughton's MS. Staffordshire Scrapbook, 379, in the William Salt Library, Stafford. 
modernizing process in Britain as science regarded as 'systematized positive knowledge'.

This examination of the Society's career encourages two sorts of conclusions about natural knowledge and its social context in provincial Britain during the period usually designated the 'Industrial Revolution' (c. 176o-c. 1840). One pertains to the development of modern scientific organizations and is so simple that it is usually not succinctly stated, which is that their successful support required a certain scale of population and of social differentiation. The scientific aims of a number of locally credible performers had to be meshed with the cultural needs of a body of willing patrons and listeners. The existence of an audience for science not only made local science possible, it also conditioned the themes, rate of development, cultural connections and social images of science, and the extent to which recognizable scientific roles were permitted to develop.

The second set of conclusions about science and its local context relate to the nature of and reasons for the social support of science. It is simply that science served a very important function in the cultural legitimation of modern urban and industrial society in late eighteenth- and early nineteenth-century Britain. This is emphatically not the same thing as asserting wide-spread or strategic links between science and economic growth or between science and industrialization. And there is in the example at hand no shred of evidence that the joint activities of manufacturers and men of science produced any invention, innovation or application of science which was economically beneficial. As Peter Mathias has recently and convincingly argued, one ought not in such cases mistake technical aspiration and endeavour for economic result. ${ }^{59}$

At the same time one ought to give aspiration and endeavour their historical due and to recognize in men's hopes, attitudes and understanding a central role of science in the changing context of Industrial Revolution Britain. The new men of urban, industrial Britain wanted two distinct things from their participation in science. ${ }^{60}$ First, they wanted a form of culture which seemed to embody their own way of experiencing the world and which affirmed their values. To the extent that science might be viewed

59 Peter Mathias, 'Who Unbound Prometheus? Science and Technical Change, I60o1800', in A. E. Musson (ed.), Science, Technology and Economic Growth in the Eighteenth Century (London, 1972), 69-96 (esp. 71-74).

60 Much of the following discussion owes its origins to conversations with Professor Arnold Thackray of the University of Pennsylvania and pertains as much to his continuing work on the Manchester Literary and Philosophical Society as it does to my own. His critical reading of an earlier draft of this paper has much improved it. 
as progressive, anti-authoritarian, egalitarian, empirical, down-to-earth, and common-sensical, it was their form of culture-the chosen cultural vehicle of the makers of the new socio-economic order and their minions. The dream of applying science to industry was in very many cases just thatthe reflection of men's hopes that their elected entrée into literate culture could be given greater meaning by its utility to their primary economic activity.

But the anti-elitist and change-affirming aspects of science were thoroughly tempered by a local context in which participants in culture, of any sort, strove to demarcate themselves from both their uncouth fellows and from the lower orders of their society. Science was not only the symbol which distinguished many progressive industrialists in Britain, it also distinguished them from the great majority of their local colleagues and associates who had no literate culture. And, as the rhetoric attached to the founding of the Mechanics' Institutes demonstrates, many people were aware that the change-affirming, anti-authoritarian aspects of science might go too far, especially as they threatened to cross the lower boundaries of the industrial middle-class. The affirmation of respectability, order and theological purity therefore came to be a strong component of the Philosophical Society's propaganda.

The utility of science has to be pried loose from its purely economic associations and must be seen as a far more diffuse and vital concept. Interpenetrating and connecting the spheres of psychology, theology, class, and the political, social and economic orders, utility emerges as the shifting fulcrum upon which the disparate cultural functions of science were delicately balanced. 